\title{
Rasga Coração, de Vianinha, e Hair: aproximação e distanciamento num contexto de contracultura
} Éwerton Silva de Oliveira ${ }^{1}$

Oduvaldo Vianna Filho (1936-1974) - também conhecido como Vianinha - é um dos grandes dramaturgos brasileiros. Entre suas principais obras, estão peças como Chapetuba F. C. (1959), Mão na luva (1966), e Papa Highirte (1968). Sua última peça foi Rasga coração (1974), considerada por muitos críticos a grande obra de seu repertório. Encenada somente cinco anos após a morte de Vianinha, devido à censura da ditadura militar vigente no país, ela apresenta o conflito entre um pai comunista (Manguari Pistolão) e um filho adepto dos valores hippies e da contracultura (Luca). Tal conflito está arraigado numa estrutura formal que permite a apresentação simultânea do plano do passado e do presente no palco, e o resultado é a construção de uma análise da história do Brasil e de suas lutas políticas que começa no início do século XX e se estende até os anos 1970.

Os anos 1960 e 1970 apresentaram ao público certas inovações em relação à estética teatral, que tentavam acompanhar as transformações históricas daquele momento. Em entrevistas que concedeu, o dramaturgo carioca costumava analisar algumas formas estéticas inovadoras no teatro brasileiro. Isso é exemplificado numa entrevista sua a Luís Werneck Vianna, quando Vianinha comenta sobre Arena conta Zumbi (1965), peça organizada pelo Teatro de Arena e que apresenta, entre outras características, simultaneidade temporal, análise histórica da questão da escravidão e recursos tais como música, dança, diálogos, slides:

E soltam um teatro altamente criativo, elétrico, que traz uma série de novas formas, que o teatro brasileiro esboça em alguns espetáculos, como Arena Conta Zumbi (que é a simultaneidade) [...]. Quer dizer - o espetáculo Arena Conta Zumbi já tem muito disso, desta simultaneidade, estas coisas correndo, as diversas coisas sendo causa e efeito de si mesmas, quer dizer, o contraditório, as contradições da realidade seriam muito imbricadas (Peixoto, 1983, p. 167-8).

\footnotetext{
${ }^{1}$ Doutorando em letras no Departamento de Letras Modernas (DLM) da Faculdade de Filosofia, Letras e Ciências Humanas (FFLCH) da Universidade de São Paulo (USP), São Paulo, SP, Brasil. E-mail: ewertonc131@yahoo.com
} 
Havia também inovações no teatro feito fora do Brasil, que, muitas vezes, chegavam ao país em pleno contexto de ditadura militar. É o caso de Hair (1967), escrito pelos atores norte-americanos James Rado e Gerome Ragni.

Hair estreou no Public Theater em 2 de dezembro de 1967, com direção de Gerald Freedman, seguindo para a Broadway no ano seguinte. O musical é um dos primeiros e o grande sucesso de bilheteria entre os chamados Rock Musicals. É conhecido por romper com estruturas tradicionais do gênero, apresentando elementos como quebra da quarta parede (em que os atores dialogam e interagem diretamente com o público) e uma narrativa não linear, com um enredo que é interrompido por músicas, comentários, performances. E, entre suas principais inovações, está o fato de que Hair apresenta valores da contracultura, tais como a discussão sobre a guerra do Vietnã, sobre questões ambientais e a sexualidade.

No Brasil, o musical foi produzido em 1969, logo após a instauração do Ato Institucional $n^{\circ} 5$ (AI-5), que deu plenos poderes ao executivo dominado pela ditadura militar. Entre outras coisas, o AI-5 permitiu perseguições a opositores políticos, jornalistas, artistas, além de incentivar a censura de textos, programas de televisão, filmes, peças e outras obras artísticas. Hair teve problemas com a censura, especialmente no que tange às cenas de nudez presentes no musical; mesmo assim, com restrições, ela foi liberada para a encenação. Entre os atores de Hair em solo brasileiro, estiveram Sônia Braga, Armando Bogus e Aracy Balabanian. ${ }^{2}$

O que chama a atenção, tanto em Rasga coração quanto em Hair, é a possível aproximação que pode ser feita entre os jovens do musical e personagens também jovens presentes na peça de Vianinha, em seus desejos por mudanças na estrutura social e cultural vigente, com ideias inovadoras, mas também contradições. A comparação entre as personagens de Hair e de Rasga coração, num contexto de contracultura, é o objetivo deste texto.

A contracultura aparece no contexto dos anos 1960 em concomitância com várias manifestações políticas que estavam surgindo ao redor do mundo neste período, sobretudo entre os jovens da época (mas também entre os trabalhadores de diversos setores sociais), e que

\footnotetext{
${ }^{2}$ Sobre a estreia de Hair no Brasil, ver Hair - 1969, 2008.
} 
tiveram o seu ápice em 1968, especialmente na França, com atos tais como greves gerais e ocupações de universidades organizadas por movimentos estudantis. O objetivo era conseguir mudanças e melhorias na estrutura social e econômica.

No entanto, estes movimentos liderados pelos jovens, com diversas correntes de pensamento e presentes em vários países, se destacaram não só pela luta por mudanças econômicas, mas também por mudanças no plano social e cultural.

Theodore Roszak é um dos teóricos mais conhecidos por estudar e definir o que seria a contracultura. Em seu livro O nascimento de uma contracultura, ele comenta sobre o fato de que, nos anos 1960 e 1970, um grande número de jovens passou a ter interesse por estudos e práticas culturais e sociais que destoavam da rotina de seus pais. De certa forma, isto acaba sendo visto como forma de contestação ao modo de viver de seus genitores:

Para mim é óbvio e indiscutível que o interesse de nossos adolescentes e estudantes por questões como a psicologia da alienação, o misticismo oriental, as drogas psicodélicas e as experiências comunitárias compreende, em conjunto, uma constelação cultural que difere radicalmente dos valores e concepções fundamentais de nossa sociedade, ao menos desde a Revolução Científica do século XVII (Roszak, 1970, p. 10, tradução nossa).

Várias questões que antes eram raramente discutidas passaram a ser parte da preocupação dos jovens dos anos 1960 e 1970. Dentre elas, podemos destacar:

As transformações da imagem da mulher, com o feminismo; a liberação sexual; as modificações na estrutura da família; a entronização do modo jovem de ser como estilo de vida; a flexibilização das hierarquias e da autoridade; a construção de novas relações entre o adulto e o jovem e o adulto e a criança; a criação de um novo imaginário da fraternidade; a introdução do "novo" na política; a emergência das questões ecológicas como se fossem também políticas, para ficar com algumas das referências mais destacadas (Cardoso, 2005, p. 93).

Suas formas de mobilização e contestação também destoavam do que vinha sendo praticado até então. Elas eram lutas 


\begin{abstract}
"transversais", não limitadas a um país; eram "imediatas", contestavam o poder mais próximo e não esperavam soluções dos problemas no futuro (isto é, liberações, revoluções, fim da luta de classe), "lutas anárquicas"; lutas contra o "governo da individualização" e a afirmação do "direito de ser diferente"; "lutas contra os privilégios do saber"; lutas que giram em torno da pergunta "Quem somos nós?" (Cardoso, 2005, p. 97).
\end{abstract}

A postura política da juventude dos anos 1960 e 1970 é algo tão complexo e tão particular em cada região do mundo e em cada grupo social que Roszak anuncia, no prefácio, que seu estudo terá como foco principal somente estes jovens "contraculturais", que procuraram o misticismo oriental e as experiências comunitárias, por exemplo, como forma de contestação e escape de uma sociedade que produz lucros e guerras. Ele deixa a entender que as lutas tais quais as dos jovens marxistas e dos negros pelos direitos civis mereceriam estudos à parte, mais específicos e aprofundados.

Deste modo, se considerarmos o surgimento da contracultura nos Estados Unidos (local em que o musical Hair foi criado) e no Brasil (onde Rasga coração foi encenada), por exemplo, veremos também esta complexidade apontada por Roszak não só com semelhanças quanto a determinadas características desta contracultura, mas também com especificidades e diferenças referentes a cada processo histórico - seja o americano, seja o brasileiro.

Os jovens adeptos da contracultura colocaram em xeque pressupostos sociais, culturais e comportamentais de seus pais e da estrutura social vigente, enfatizando e defendendo questões como a necessidade da preservação ambiental, a possibilidade da livre sexualidade e até mesmo o uso de drogas e o direito de ser e de se vestir como quiser, com a liberdade individual para fazer isso. Nos Estados Unidos, tais reflexões surgiram em concomitância com movimentos sociais tais como a mobilização em favor dos direitos civis aos negros, a luta por melhorias às mulheres e os movimentos pacifistas contra a guerra do Vietnã:

Nos Estados Unidos, a reação contra a guerra do Vietnã e contra a discriminação racial também conduziria a formas de contestação antissistêmicas, mas de outro cunho: a recusa ao alistamento militar; as grandes mobilizações pelos direitos civis; a rejeição aos moldes do way of life antisséptico e bem-comportado, a recusa da 
competição desenfreada, expressa através da contracultura, das drogas, de utopias imediatas (os hippies e suas comunidades) (Fontes, 1998, s.p.).

No caso da mobilização contra a Guerra do Vietnã, por exemplo, apesar de sabermos que os movimentos pacifistas abrangiam diferentes setores sociais dos Estados Unidos, chama a atenção a ligação que havia entre contracultura e esta luta em favor da paz. Anderson (2002, p. 141), ao relembrar que os canais televisivos norte-americanos transmitiam tanto imagens do conflito bélico como dos protestos contra a guerra, comenta que as câmeras costumavam focar nos membros "pitorescos" da multidão que protestava contra a intervenção norte-americana em solo vietnamita, o que dava a muitos telespectadores a impressão de que todos os manifestantes pacifistas eram hippies, ou seja, adeptos da contracultura.

Se, em solo americano, a contracultura surge em concomitância com os movimentos citados, no Brasil, ela se manifestará com características semelhantes às dos Estados Unidos (como a luta contra a destruição ambiental e em favor da paz), mas assumindo feições próprias.

O Brasil vivia sob uma ditadura militar que se iniciara em 1964. Havia setores sociais que tentavam lutar contra o regime ditatorial - seja por forma de mobilização coletiva destes diversos setores da sociedade, seja por meio da luta armada, em que muitos jovens da época decidiram pegar em armas e organizar grupos de guerrilha com o objetivo de derrubar a ditadura.

No entanto, com a instauração do Ato Institucional n 5 (AI-5), em 1968, a repressão ditatorial a estes movimentos de oposição se tornou ainda mais intensa e violenta. Tal medida governamental contribuiu, por exemplo, para o extermínio dos grupos de guerrilha e para a morte de muitos jovens que optaram pela luta armada como forma de engajamento político:

A oposição armada estava totalmente liquidada em meados de 1974, o que não impediu que os militares da linha dura explorassem a alegação da permanência da ameaça de guerrilha para manter os militares moderados na defensiva e justificar o prosseguimento da repressão (Skidmore, 2003, p. 235).

Diante da constante repressão governamental, outros jovens da época tentaram aderir à contracultura como uma alternativa de vida. De certo modo, era uma forma de escape e uma tentativa de protesto contra este momento político conturbado do país: 
A contracultura brasileira é em geral descrita como uma das duas vias pelas quais a rebeldia da juventude de classe média trafegou a partir do AI-5. Ao contrário do terceiro grupo que, segundo Syrkis, "aderiu" às benesses do Sistema, e diferentemente do primeiro, que abraçou a guerrilha, a morte ou o exílio, os desbundados romperam com o sistema pela via comportamental, recusando-se a participar dos ritos sociais consagrados pela tradição ocidental (Capellari, 2007, p. 44).

No entanto, como será visto adiante, a contracultura sofreu duras críticas no Brasil durante o período ditatorial porque muitos a consideraram, nesse momento histórico, uma tentativa de fuga e alienação à luta política contra a ditadura.

Assim, é necessário ver a contracultura como um movimento complexo, híbrido, e específico em cada região e setor social em que se manifestou:

Quando se produz o mito, com o congelamento de uma imagem identitária, o que se estanca é o movimento da história e da memória (a historicidade dos movimentos), anulando a perspectiva de uma referência histórica maior que vá além dos estreitos limites da década, assim como os aspectos de heterogeneidade e conflito que caracterizaram aqueles movimentos (Cardoso, 2005, p. 102).

Esta foi apenas uma pequena apresentação de algumas características e especificidades da contracultura nos Estados Unidos e no Brasil. No entanto, este movimento de jovens dos anos 1960 e 1970 é algo muito complexo para que um breve artigo possa analisar toda a sua dimensão e todo o seu impacto especificamente nestes dois países. A ideia da análise que será feita a seguir, porém, é contribuir para os estudos sobre a contracultura e sobre processos históricos americanos e brasileiros, demonstrando elementos de aproximação e distanciamento, em suas lutas políticas e contradições, entre os jovens contraculturais de Brasil e Estados Unidos representados, respectivamente, na peça Rasga coração (de Vianinha) e no musical Hair.

O tênue fio de enredo do musical Hair conta a história de Claude, um jovem que ama a liberdade e a paz, mas se vê obrigado pelo governo dos Estados Unidos a lutar e a morrer no Vietnã (a peça termina justamente com a ida do rapaz à guerra). Durante o musical, Claude e os outros jovens (tais como seu amigo Berger e Sheila, universitária e engajada em 
questões políticas e culturais) tentam praticar um estilo de vida hippie, com música, sexo e contestação ao modo de viver de seus pais:

Claude Hooper Bukowski, um jovem rapaz que procura refúgio de seus pais de classe média e de sua casa no Queens no reduto hippie de Greenwich Village, discute se deve ou não ir lutar no Vietnã. O rapaz vive este dilema enquanto passa tempo com seus amigos, briga com os pais e corre atrás de Sheila, uma estudante politicamente engajada da Universidade de Nova York. No final, Claude vai para o Vietnã, onde é morto. O musical termina com seus amigos reunidos para celebrar sua vida e chorar sua morte precoce e estúpida (Wollman, 2006, p. 47, tradução nossa).

Na peça de Vianinha, Rasga coração, os representantes mais diretos da contracultura são Luca e sua namorada, Milena. O primeiro, filho de Nena e de Manguari, um funcionário público e militante do Partido Comunista Brasileiro (PCB), tenta ter um modo de vida hippie, parecido com o de Claude, com paz, amor, e sintonia com a natureza, apesar do desejo de seu pai de que se torne um militante comunista (algo que não acontecerá).

Do mesmo modo, tal como Sheila em Hair, na peça brasileira Milena apresenta elementos contraculturais e um desejo de luta política e social que remete ao movimento feminista e a mobilizações políticas de outros tipos.

Em ambas as peças, temos rapazes e moças imbuídos de ideias da contracultura; eles criticam e vão contra opressões que, naquele momento, precisavam ser criticadas, tais como a guerra do Vietnã e a poluição ambiental. Estes jovens, presentes em Rasga coração, Hair e na realidade histórica dos anos 1960 e 1970, acabaram se tornando uma importante fonte de contestação de injustiças e problemas sociais.

Chama a atenção, por exemplo, a frase de Hud, um dos jovens de Hair, ao demonstrar sua consciência de que a guerra do Vietnã fazia parte de mais um capítulo do imperialismo praticado pelo governo dos Estados Unidos no mundo: "O recrutamento para a guerra consiste em brancos mandando negros para lutar contra 'amarelos' [asiáticos] no intuito de defender a terra que estes mesmos brancos roubaram dos 'vermelhos' [índios]" (Ragni e Rado, 1970, p. 74, tradução nossa).

A luta contra opressões e guerras (sobretudo a do Vietnã) reverbera nos jovens contraculturais do Brasil, como exemplifica a personagem 
Luca, de Rasga coração, ao comentar sobre os problemas sociais, ambientais e individuais que ele vê em seu tempo:

LUCA: ... gás S02, brometos, DDT, 40 toneladas de corante, é isso que as pessoas comem! Vocês estão comendo coisas mortas, fúnebres, e isso é que explode dentro do sangue de vocês! Hein? E para fugir desta morte, hein? Essa ansiedade! Pra afogar essa ansiedade vocês resolveram fazer o reino da fartura e pulam em cima da natureza, querem domá-la à porrada e comem morte e engolem carnes, bloqueiam o corpo, os poros, sobra o cérebro pensando incendiado em descobrir um jeito de não viver e a tensão toma conta de tudo e vocês só parem guerras, as guerras pela justiça, pela liberdade, dignidade e nada descarrega a tensão, o cheiro de podre vem de dentro, o sexo entra pelas frestas, sobra o sexo nas noites solitárias martelando, então mais guerra e napalm e guerras... (Vianna Filho, 1979, p. 32).

Os jovens de ambas as peças, baseados nas ideias da contracultura, também são a favor do respeito à natureza e se opõem à poluição, aos agrotóxicos e a outros produtos que podem prejudicar o meio ambiente. A música "Exanaplanetooch", do musical norte-americano, mostra o desejo desta geração de sair do planeta Terra e viver em:

Um planeta que respira puro ar

$\mathrm{E}$ as águas do rio tendem a brilhar

Seu céu tem a cor verde

E ao véu da noite ascendem

As doze luas douradas

Deixa a noite iluminada (Ragni e Rado, 1970, p. 191, tradução nossa).

Luca também critica a destruição ambiental com a qual se depara:

LUCA: ... Já foram encontrados pinguins com inseticida no corpo, a Europa já destruiu todo seu ambiente natural, diversas espécies de animais só existem nos jardins zoológicos, as borboletas estão acabando, vocês vivem no meio de fezes, gás carbônico, asfalto, ataques cardíacos, pílulas, solidão... essa civilização é um fracasso, quem fica nela e se interessa por ela, essas pessoas é que perderam o interesse pela vida... eu é que devia te chamar pra largar tudo isso... é na pele a vida, é dentro da gente, vocês não sabem mais se maravilhar! Eu não estou largado pai, ontem estive 
na porta de uma fábrica de inseticida, fui explicar pros operários que eles não podem produzir isso... (Vianna Filho, 1979, p. 72).

No entanto, paralelamente à defesa em favor da preservação da natureza, esta geração adepta da contracultura celebra, por exemplo, elementos tecnológicos e eletrônicos. O gênero musical rock'n'roll, com suas guitarras elétricas, está presente na vida das personagens jovens de Hair e de Rasga coração. No início do segundo ato da peça norteamericana, observamos a descrição de uma "música furiosa" tocada pela banda Banheira Intergaláctica Eletrificada (no original, "Intergalactic Bathtub Electrified"), com a presença, no palco, de muitos fios elétricos em todo o lugar, além de amplificadores, guitarras elétricas e microfones (Ragni e Rado, 1970, p. 121, tradução nossa). Do mesmo modo, a guitarra elétrica aparece em Rasga coração por meio desta fala de Nena, mãe de Luca: "e é disco todo dia que ele [Luca] compra, uma guitarra elétrica aí, nem tocou nela" (Vianna Filho, 1979, p. 23).

Uma das coisas que chama a atenção, tanto na peça americana quanto na brasileira, é a concepção trazida pela imagem do cabelo dos jovens representados nas duas obras teatrais. Um dos fatos estruturais de Rasga coração, por exemplo, é que Luca se revolta contra o ato do diretor da escola, Castro Cott, de proibir os alunos de usarem jeans, tênis, calça comprida (para as moças) e, principalmente, cabelos compridos (no caso dos rapazes): “NENA: Você não tinha que estar no colégio, filho?/ LUCA: Não posso mais entrar. Não entra mais aluno de cabelo comprido" (Vianna Filho, 1979, p. 39).

Como Luca começa a se mobilizar contra tal proibição, Manguari vê a possibilidade de que seu filho inicie uma militância de esquerda a partir de então; no entanto, a repressão violenta da diretoria da escola aos alunos que contestavam esta regra e a consequente expulsão de Luca e Milena do colégio, entre outros fatos, fizeram com que o rapaz tomasse outros caminhos em sua vida, diferentes dos desejados pelo pai.

Do mesmo modo, em Hair, Claude, ao ser recrutado pelo exército americano para a guerra no Vietnã, se vê obrigado a cortar o cabelo:

SHEILA: Eu cortei o cabelo dele... ele me pediu...

CLAUDE: Eu não queria que eles cortassem o meu cabelo. Aqui, George, eu quero que você fique com ele (Claude dá para Berger um saco com o cabelo cortado) (Ragni e Rado, 1970, p. 200, tradução nossa). 
Claude se torna vítima do alistamento militar compulsório, sendo forçado a se inserir na estrutura social que permite a guerra, e, para tanto, tem de cortar os cabelos. Luca não o faz, mas paga um preço alto por isso: é coagido e expulso da escola, e decide não mais estudar, o que gera um isolamento do sistema social - simbolizado pelo colégio que reproduz as tensões e as ideologias presentes na sociedade.

Deste modo, os cabelos compridos (que estão, por exemplo, no próprio título do musical - "cabelo", em inglês) são símbolo de uma tentativa de luta para obter o direito à escolha individual, de utilizar as roupas e o estilo de vida que se quer - inclusive cabelos fora do padrão social estabelecido. Tanto Claude quanto Luca lutam contra um sistema sociocultural que padroniza e não aceita o diferente, e ambos são de certa forma derrotados nesta luta - o primeiro morre na guerra e o segundo tem de se isolar socialmente para viver como deseja, sem conseguir, inicialmente, nenhuma mudança na estrutura social. Além disso, o cabelo está sobre a cabeça, de onde vêm as ideias. Cortar o cabelo, neste caso, poderia significar também uma estrutura de poder tentando ceifar a renovação de ideias que potencialmente viria destes movimentos de jovens dos anos 1960 e 1970.

Assim como Luca é banido de sua escola, alguns jovens de Hair abandonam ou também são expulsos do colégio. Nas duas obras teatrais, os rapazes e moças, de certa forma, tentam se rebelar contra a instituição escolar, vista por eles como símbolo da sociedade opressora em que vivem, e reprodutora de conhecimentos sem vida, que criam diferenças e opressões sociais. Luca diz ao pai: "mas vou continuar dando este espetáculo, sim! É só isso que eu quero aprender, não tenho nada para aprender nas universidades de vocês, nada!" (Vianna Filho, 1979, p. 74). Do mesmo modo, no musical americano, Berger afirma que "odeia a escola" (Ragni e Rado, 1970, p. 26, tradução nossa), e o "Pai" comenta o que é a instituição escolar sob o ponto de vista dos jovens hippies nos Estados Unidos daquele período: “o governador Reagan disse que as escolas têm que se tornar campos de concentração" (Ragni e Rado, 1970, p. 33, tradução nossa).

Chama a atenção também que, no musical americano, o secretário de defesa dos Estados Unidos durante a guerra do Vietnã, Robert McNamara, aparece como diretor da escola. Da mesma forma, em Rasga coração, o diretor é Castro Cott, um adepto do integralismo e do 
fascismo - o que indica o aspecto de repressão presente nas escolas representadas nos textos.

Virgínia Fontes $(1998$, s.p.) comenta como a crítica à estrutura escolar (feita por personagens de ambas as peças) era parte da crítica da geração adepta da contracultura às instituições em geral, vistas como reprodutoras de opressões e repressões: "O conhecimento, as escolas, as organizações políticas, as associações, as instituições, as empresas; a linguagem e a moda; as relações de gênero e a família passavam a ser percebidas como produtoras também de disciplinas, hierarquias, controles e sujeição".

Deste modo, os jovens passam a buscar as suas próprias formas de estudar e obter conhecimento, que destoavam daquelas ensinadas em colégios e universidades. No material de pesquisa compilado por Vianinha (com o auxílio de Maria Célia Teixeira), que serviu de apoio na composição de Rasga coração, aparecem análises que o dramaturgo carioca fez do livro de Theodore Roszak sobre os estudos feitos pela juventude daquele período. Estes estudos não condiziam com aqueles oferecidos pela escola tradicional:

Theodore Roszak (p. 58): Curriculum da Antiuniversidade: Descrição do curso: uma sucessão livre de situações abertas. Vibrações momentâneas altamente relevantes. Exploração do espaço interior, descondicionamento do robô humano, significação de produtos psicoquímicos e a transformação do Homem Europeu Ocidental. Fontes. Artaud, Zimmer, Gurdjieff, W. Reich, K. Marx, textos gnósticos, sufistas e Tântricos, relatos autobiográficos de loucura e estados extáticos de consciência Pop-art e prosa do século XX. Realmente bastante forte. Mas um exemplo típico do estilo da universidade livre. Com muita frequência, tal esforço intelectual dirigido por instrutores mal saídos da adolescência degenera numa louvação semiarticulada e indiscriminada de tudo que seja novo, estranho e barulhento: um manuseio de ideias muito semelhante à maneira como o bebê brinca com objetos brilhantes e desconhecidos (Vianna Filho, 1979, p. 270-1).

Assim como discussões sobre a preservação da natureza e sobre as instituições escolares, outro aspecto presente tanto em Hair como em Rasga coração é a imagem da mulher lutando por mais direitos e melhorias e intensificando sua participação em lutas políticas e culturais - algo que foi parte, por exemplo, do movimento feminista dos anos 
1960 e 1970. No musical americano, Sheila, uma estudante da Universidade de Nova York, "ama protestar no parque" e é inclusive descrita como "Joana d'Arc":

CLAUDE: Quando você entrou? Eu pensei que você estava fazendo piquete em [Washington] D.C.

BERGER: Protestando!!!

SHEILA: Espalhando a revolução groovy³ (Ragni e Rado, 1970, p. 72 , tradução nossa).

Podemos fazer um paralelo entre Sheila e Milena, a namorada de Luca em Rasga coração. Também de classe média alta, social e politicamente engajada, Milena defende que os alunos invadam o colégio, numa "ação direta", para lutarem contra a proibição do uso de cabelos compridos e determinadas vestimentas imposta pela direção escolar. Tal invasão termina com a destruição de arquivos de provas e com a expulsão de Luca e Milena da escola: "MILENA: Ele chama de golpismo ir pra rua de peito aberto pro pau! Ação direta!" (Vianna Filho, 1979, p. 59).

No entanto, embora ambas representem, de certa forma, a militância feminista, Milena possui a peculiaridade de fazer esta luta no Brasil dos anos 1960 e 1970, num contexto de ditadura militar - o que torna sua mobilização algo diferente dos protestos organizados por Sheila e presentes nos Estados Unidos no período. Na peça brasileira, Milena representa, entre outras coisas, a luta armada desenvolvida no país para derrubar o governo militar, sendo que esta luta armada foi sumariamente reprimida pelos militares no poder naquele momento. ${ }^{4}$

Também estão inseridos na contracultura o questionamento e a contestação a todo tipo de autoridade - política, paterna, escolar, entre outros -, já que os jovens viam a autoridade como responsável pelas crises sociais de seu tempo. Milena, por exemplo, não aceita as regras de sua escola, e as contesta sistematicamente:

MILENA (Pontua com sintetizador a fala): ... ah, não pode ir a aula de calça comprida? Então hoje eu fui com esse vestido, olha a

\footnotetext{
${ }^{3}$ De acordo com o dicionário Cambridge, groovy é uma gíria considerada "datada" para os dias de hoje (dated slang) e se refere a algo que está na moda (fashionable) e é interessante (interesting) (Groovy, s.d., s.p.).

${ }^{4}$ Entre os estudos que analisam Rasga coração com mais profundidade, ver Betti, 1997. A relação entre a personagem Milena e a luta armada no país no período ditatorial também é estudada em Oliveira, 2012.
} 
calcinha quase transparente, sentei na primeira fila, abri a perna e fiz a distraída, ninguém deu aula direito, saca? Os professores suando, volta e meia o olho batendo na minha coxa (Vianna Filho, 1979, p. 45).

Sheila, por sua vez, contesta a autoridade mostrando o excesso de proibições existentes na sociedade em que vivia. Isso é exemplificado em sua fala: "É proibido andar de bicicleta, andar de skate, jogar lixo na rua, dar um rolê, cuspir, fumar, comer [...], falar, cantar, olhar, respirar, amar" (Ragni e Rado, 1970, p. 92, tradução nossa).

A contestação à autoridade é traduzida pelo conflito entre pais, que são vistos como portadores de valores "ultrapassados" e que geram proibições e opressão, e filhos com perspectivas diferentes das paternas, com ideais cujo entendimento os pais não possuem. No caso americano, por exemplo, há genitores que têm orgulho de ser americanos e jovens que não concordam com a política bélica dos Estados Unidos contra o Vietnã. A personagem do musical denominada "Mãe" diz: "Vocês jovens não valorizam a maturidade e a sabedoria que a idade traz", e se dirige ao público, comentando: "Meu filho usa uma fita preta no braço... ele usa uma fita no braço e é contra a guerra. O pai dele tem vergonha de sair nas ruas por isso" (Ragni e Rado, 1970, p. 112, tradução nossa).

No caso brasileiro, Luca contesta e questiona a militância comunista do pai, pois acha que as concepções ideológicas defendidas por Manguari não enxergam outros problemas que fazem parte da sociedade, tais como a repressão sexual:

LUCA: Verdade que quase 70 por cento das mulheres nunca tiveram prazer sexual? [...]

E o capitalismo também é culpado?

MANGUARI: Acho que é... claro que é...

LUCA: Na Rússia como é? Cinco coitos por quinquênio?

MANGUARI: ... primeiro, parece que foi amor livre, depois... acho que teve um Sexpol - é política sexual... agora, parece que é muito moralista... o proletariado é moralista...

LUCA: Por quê? Ele não é a vanguarda revolucionária? (Vianna Filho, 1979, p. 31).

Tal como a fala de Luca demonstra, a geração contracultural de ambas as peças fala abertamente sobre sexualidade (e homossexualidade), o que assusta os seus genitores. Em Hair, o jovem Woof afirma: "Eu amo o Claude, não posso resistir a isto. Eu não sou 
homossexual ou algo do tipo... mas eu iria para a cama com ele... e ia fazer amor com você..." (Ragni e Rado, 1970, p. 138, tradução nossa).

Zinn comenta como as discussões sobre sexualidade passaram a ser muito mais intensas a partir dos anos 1960 e 1970, momento em que "poderia se falar abertamente sobre a masturbação", por exemplo. Os homossexuais, por sua vez, tiveram a oportunidade de lutar por seus direitos: "A homossexualidade não era mais escondida. Gays e lésbicas se organizaram para combater a discriminação contra eles, e para conseguir um senso de comunidade, para superar a vergonha e o isolamento" (Zinn, 2010, p. 397, tradução nossa).

A rotina e modo de vida dos pais, sob a ótica da contracultura, são vistos como conformistas diante das opressões do sistema social. Os rapazes e moças de Hair não querem, por exemplo, ter as profissões de seus genitores e almejam mudanças radicais neste sentido. Na peça, há frases como: "Eu não quero ser nada [profissionalmente], e eu certamente não quero ser uma dona de casa com filhos" (Ragni e Rado, 1970, p. 147, tradução nossa). Em Rasga coração, Luca critica o fato de o pai exercer uma militância comunista, mas, ao mesmo tempo, ser um funcionário público que há vinte e cinco anos vive a mesma rotina, pegando o mesmo "ônibus 415" para ir ao trabalho:

LUCA: Mas a experiência é pra isso? Não quero, não quero ficar experimentado! Você é que é um revolucionário, então? O mesmo ônibus 415, com trocado no bolso que não gosta de brigar com o trocador, o editorial, leu o editorial? Conversou com o jornaleiro, atravessou a rua no sinal, na faixa, 25 anos, ônibus 415 com trocado no bolso, 25 anos assinando ponto em repartição, reuniões quartasfeiras, mês de finanças, rifas para passar, recorte de jornal no bolso "leu este artigo do Tristão?" (Vianna Filho, 1979, p. 62).

Neste sentido, algo que se destaca nos jovens da década de 1960 e 1970 é o conflito geracional - ou seja, a contestação aos valores paternos e à estrutura social na qual os genitores estão inseridos:

Talvez se possa dizer que o conflito de gerações sob a contracultura tenha sido mais acentuado. A ruptura com a geração anterior teria sido mais radical, especialmente no que se refere às experiências com as drogas psicodélicas, ao misticismo oriental e às vivências em comunidade, experiências que, embora remontem a tradições anteriores, ao estarem articuladas em movimentos coletivos de contestação a certo modo de vida, com 
produções na literatura, na música e nas artes plásticas, podem ser consideradas uma invenção dos anos de 1960. Essa geração empreendeu a busca de novas formas de sensibilidade que se tornaram radicalmente críticas em relação às da geração de seus pais, que era considerada aprisionada a uma rotina conformista (Cardoso, 2005, p. 98).

Os movimentos dos jovens dos anos 1960 e 1970, incluindo a contracultura, apresentaram muitos pontos de mobilização, luta e avanços na estrutura social tanto brasileira quanto norte-americana: a maior ênfase à proteção ambiental, mais direitos políticos e sociais às mulheres, e, no caso norte-americano, grande peso político na decisão do governo dos Estados Unidos de terminar com a guerra do Vietnã, entre outras conquistas. No entanto, muito desta mobilização foi absorvida pela estrutura social contra a qual lutavam, mercantilizandose e transformando-se em mercadoria:

A dificuldade de construir opções sociopolíticas mais amplas do que cada grupo ou grupúsculo propunha, com um espectro mais largo do que as fronteiras nacionais, aliada a uma intensa mediatização de apenas alguns de seus aspectos, permitiu uma acentuada mercantilização dos elementos rebeldes, traduzidos num consumo crescente de signos de rebeldia. Tentava-se transformar a rebelião contra a uniformização na homogeneização de uma rebeldia conformada - o jeans e o rock passavam de protesto a símbolos de consumo (Fontes, 1998, s.p.).

No caso do Brasil, por exemplo, a situação se tornou ainda mais difícil com o AI-5, em 1968. Com o país num momento político complicado, muitos jovens do período acabaram por tentar encontrar outras perspectivas que lhes dessem sentido de vida fora da luta política. E muitos caminhos foram tomados, vários deles prejudiciais aos jovens, como o uso de drogas. Este fenômeno, no Brasil, é conhecido como "desbunde", tal como comenta Damasceno (1994, p. 218):

Uma expressão dos fenômenos do desbunde, a curtição era uma resposta social individualista à alienação social que se organizava coletivamente em ritos teatrais ou happenings. A espontaneidade e o entusiasmo que acompanhavam esses eventos foram formalizados pelos aspectos ritualísticos da comunicação teatral. Adicionalmente, a música, rock em especial, assumiu o papel principal na estruturação da forma teatral. 
Um exemplo de tentativa de fuga de uma sociedade opressiva é a busca que muitos destes rapazes e moças fizeram por elementos da cultura oriental - sobretudo a indiana (por exemplo, a prática de ioga) -, cuja diferença em relação ao estilo de vida ocidental é marcante. Isso está presente tanto em Hair como em Rasga coração:

JEANIE: Eu vou para a Índia... flutuar por aí... viver em pequenas cabanas em Beirute... alimentar os indianos pobres num pequeno vilarejo em algum lugar (Ragni e Rado, 1970, p. 162, tradução nossa).

NENA: ... [Luca] vai pro interior, posto de saúde, vai ser médico pelas ruas, como na Índia (Vianna Filho, 1979, p. 24).

No caso de Rasga coração, Luca inclusive ironiza Manguari, que, mesmo sendo militante comunista, quer montar um consultório particular para o filho e não entende o seu desejo inicial de ser médico no interior: "pensei que você preferisse minha decisão proletária, decisão de justiça, de levar a medicina aos desfavorecidos" (Vianna Filho, 1979, p. 31). Neste sentido, as palavras do jovem revelam contradições presentes na militância política de seu pai.

Em ambas as falas citadas, a imagem da Índia apresenta um aspecto positivo, já que demonstra o desejo dos contraculturais Jeanie e Luca de ajudar os necessitados. No entanto, a tentativa de escape de uma sociedade problemática não se limita somente à busca por culturas distantes. Há, também, um interesse por outros mundos e galáxias. No musical americano Claude "confessa" para Sheila que veio de outro planeta, chamado Exanaplanetooch. A música que tem o nome deste planeta diz que Exanaplanetooch "fica em outra galáxia", e, nela, "todas as pessoas se parecem comigo" (Ragni e Rado, 1970, p. 191, tradução nossa), ou seja, com Claude, provavelmente em seu estilo hippie. O desejo de pertencer a outro mundo, sem os problemas deste, também domina Luca, que começa a "procurar" vida em outros planetas, após ser expulso do colégio e "derrotado" em sua luta pelo livre uso de cabelos compridos:

NENA: [...] Bom, você não pode ficar assim como se fossem inquilinos no mesmo apartamento, você é o pai dele [de Luca]... ontem foram [Luca e Milena] na casa de um chofer de táxi que viu um disco voador, vão num subúrbio aí que diz que embaixo da terra tem outra civilização, você tem que falar com ele (Vianna Filho, 1979, p. 69). 
O planeta descrito por Claude na música "Exanaplanetooch" é um lugar em que só encontramos felicidade e amor, e, nele, não existe a necessidade de governo e de polícia, além de não haver guerras nem ódio. Lá, todo homem é um artista, e o potencial e as ambições de cada um são transformados em realidade. Esta última característica, de certa forma, indica outra concepção comum deste período contracultural: já que não se conseguem melhorias de ordem coletiva, muitos vão tentar se realizar individualmente:

Valorizavam-se as experiências individuais, a matriz subjetiva capaz de ampliar poderosamente a gama de reivindicações, de permitir novos contatos, de rejeitar a padronização e a uniformização crescentes. Valorizava-se a plena emergência dos indivíduos livres das amarras de todos os poderes (Fontes, 1998, s.p.).

Luca, por exemplo, vai demonstrar o seu desejo de ser "espontâneo", ou seja, individualmente original em seus pensamentos, ideias e atitudes, no qual é contestado pelo pai, cuja perspectiva comunista é orientada pela noção de coletividade:

MANGUARI: O que significa ser espontâneo num mundo de três bilhões de pessoas, não somos o clube dos quinhentos... que é ser espontâneo?

LUCA: Chi, ele nem sabe mais o que é ser espontâneo (Vianna Filho, 1979, p. 26).

No entanto, paradoxalmente, muitos destes rapazes e moças passam a buscar também a vivência em comunidades como alternativa de vida à estrutura social vigente. Isto é algo comentado por Zinn, no contexto norte-americano:

Especialmente entre os jovens, a vivência em comunidades floresceu. Algumas eram comunas verdadeiras - ou seja, baseadas na partilha do dinheiro e nas decisões comuns, criando locais em que havia intimidade, afeição, confiança. A maioria destas comunidades, [porém], eram maneiras práticas de dividir o aluguel, com diferentes níveis de intimidade, amizade e associação entre os participantes (Zinn, 2010, p. 397, tradução nossa).

Ambas as peças parecem também fazer alusão à vivência em comunidades no contexto da contracultura. Em Rasga coração, quando Luca é expulso de casa por seu pai devido ao fato de não concordar com as ideias contraculturais do filho, e o rapaz diz ao genitor que não tem 
para onde ir, Manguari faz uma referência a este tipo de estrutura comunitária: "Cala a boca, Nena, não sei como você vai viver, não é em comunidade que vocês vivem, então?" (Vianna Filho, 1979, p. 75). Do mesmo modo, esta alusão pode estar presente no musical americano quando, por exemplo, Berger pergunta a Hud: "Hud, posso colocar minha barraca aqui esta noite?" e este diz: "Sinta-se à vontade" (Ragni e Rado, 1970, p. 49, tradução nossa).

$\mathrm{O}$ aspecto mais negativo presente em certas práticas contraculturais foi provavelmente a utilização de drogas como forma de escape aos problemas sociais e individuais. Após serem expulsos do colégio, Luca e Milena, por exemplo, passam a utilizá-las. Nena, mãe de Luca, comenta com seu marido sobre isto: "[Luca] Não toma mais banho, não toma. Três meses, Custo, indo todo o dia pra Santa Teresa, um convento, não sei o que é, não me deixa varrer o quarto, a vitrola que minha cabeça não aguenta, acho que ele toma estas drogas, hein?" (Vianna Filho, 1979, p. 69). Hair, por sua vez, apresenta rapazes e moças que defendem e usam drogas abertamente, demonstrando o lado de contradição e derrota do movimento contracultural. No caso do musical americano, isto é exemplificado na música citada a seguir, que faz menção à maconha (marijuana, em inglês): "Mari Juana Mari Juana / Juana Juana Mari Mari" (Ragni e Rado, 1970, p. 112, tradução nossa).

Martínez (2012, p. 154) comenta sobre o uso das drogas no contexto da contracultura - um aspecto negativo presente no movimento e que foi percebido por Roszak:

Hoje podemos, com a sempre irritante "sabedoria a posteriori", permitir-nos ser sarcásticos sobre alguns ideais dessa "contracultura", como a de utilização de drogas psicodélicas para "expandir a consciência". Roszak era perfeitamente consciente desse perigo e dedica o capítulo V de seu livro ao "Uso e abuso da experiência psicodélica", desautorizando os formadores de opinião e "intelectuais pops" da época, como Timothy Leary.

No contexto da contracultura, o desejo de escape deste mundo cheio de crises sociais é tão grande, que até o pensamento racional e as palavras são criticadas ou questionadas:

Assim como para as contraculturas nos Estados Unidos e na Europa no final dos anos 60, o pensamento discursivo ou analítico foi reduzido a perífrases, ou a partículas expletivas. O descrédito dessa geração nas palavras é compreensível, dado o clima de 
confusão verbal e desinformação ou informação parcial sobre a situação autoritária no qual ela chegou à maturidade (Damasceno, 1994, p. 218).

Luca, sob este ponto de vista, analisa a palavra "vestibular": "Vestibular é uma palavra engraçada... ela não diz o que é a coisa... vocês não tem [sic] cuidado com as palavras" (Vianna Filho, 1979, p. 74); da mesma forma, em Hair, há uma música que menciona várias termos ligados à sexualidade (masturbação, pederastia), e que pergunta: "Por que estas palavras soam tão ofensivas?” (Ragni e Rado, 1970, p. 10, tradução nossa).

Tal geração demonstra as contradições em suas próprias frases. Isto está explícito, por exemplo, em algumas falas de Claude durante o musical: "Eu não quero ser um dentista ou um advogado ou um vagabundo ou uma máquina da IBM. Eu não quero ser um herói do rock'n'roll nem uma estrela de cinema. Só quero ter muito dinheiro" (Ragni e Rado, 1970, p. 162, tradução nossa). O rapaz, que se torna soldado, também mescla o novo com o velho, comentando que esta é "a era dos dinossauros eletrônicos e dos índios cibernéticos e do Daily News, a era em que é mais divertido do que nunca ser jovem". Além disso, Claude diz a personagens e público que "esta é a sua era" e que "vocês estão vivendo" esta era (Ragni e Rado, 1970, p. 14, tradução nossa), representando o momento histórico de uma geração ansiosa por viver e lutar pelo agora, sem ter como principal foco de preocupação o passado ou o futuro (e o gerúndio desta última fala - ou seja, as ações do "agora" - chamam a atenção).

Assim, o movimento político-cultural dos jovens dos anos 1960 e 1970, incluindo a contracultura, que aparece representado tanto em Hair quanto em Rasga coração, apresentou aspectos inovadores de mobilização, tentativa de mudança e melhorias sociais, que trouxeram benefícios para a sociedade atual - tanto nos Estados Unidos quanto no Brasil; no entanto, demonstrou também um viés que enfatiza tentativas de escape e alienação de uma realidade com problemas coletivos e individuais.

Tanto o musical estadunidense Hair quanto a peça brasileira Rasga coração são conhecidos por não apresentarem uma estrutura dramática tradicional. As obras inclusive recebem críticas por isto, como acontece no caso da peça norte-americana. Barnes (1967), por exemplo, acredita que haja a falta de um enredo mais "desenvolvido" em Hair: 
Se Hair tivesse uma história - o que na verdade ela não tem - esta história seria sobre um jovem desencantado, mergulhado em drogas, destruído pelo alistamento, vivendo e amando [...]. Isto, se o musical tivesse uma história, seria o seu assunto (Barnes, 1967, s.p., tradução nossa).

No entanto, o rompimento com a estrutura dramática, presente tanto em Hair quanto em Rasga coração, permite uma representação e uma análise mais abrangentes de questões históricas e sociais que, naquele momento, precisavam (e ainda precisam) ser analisadas. Embora o tênue enredo da obra estadunidense, por exemplo, se baseie na transformação de Claude, de hippie a soldado enviado para a guerra, o musical é permeado por elementos não dramáticos, como quebra da quarta parede (ou seja, atores dialogando com o público), narrativa não linear, músicas que comentam as situações sociais e individuais, e personagens que interpretam outras personagens (incluindo nomes famosos da história norte-americana, de diferentes épocas, que são representados pelos jovens da peça):

É, certamente, fácil considerar Hair um musical desprovido de um enredo coeso, já que ele é estruturado em quadros interligados, durante os quais as muitas personagens do musical examinam várias questões contraculturais. Músicas frouxamente ligadas e esquetes exploram temas como o uso de drogas e a sexualidade, práticas religiosas e espirituais do Oriente, o movimento dos direitos civis, questões de classe, o conflito de gerações e a Guerra do Vietnã. Para unir tais quadros, entretanto, temos um enredo coeso, ainda que se pareça com um esboço (Wollman, 2006, p. 47, tradução nossa).

Do mesmo modo, Rasga coração é uma obra que, embora apresente, no plano do presente, o conflito entre Luca e Manguari, resultando no rompimento de ambos no final da peça, possui um plano do passado, que se mistura ao do presente, para analisar fatos da história do Brasil, especialmente a época em que Manguari tinha a idade de Luca (anos 1930 e 1940). Na peça brasileira notam-se também elementos como a quebra da quarta parede, músicas que comentam as situações sociais e das personagens, e a ausência de linearidade temporal, com simultaneidade entre passado e presente: 
Embora algumas vezes o passado irrompa em cena a partir da carga associativa das lembranças de Manguari, o contraponto cênico de acontecimentos é exterior à sua subjetividade e se apresenta como um eixo épico que estrutura e propele o desenrolar dramatúrgico do material figurado. [....] $\mathrm{O}$ contraponto cênico entre os tempos tem natureza essencialmente política no efeito que produz, ressaltando as implicações e contradições das experiências das diferentes gerações representadas dentro dos diferentes planos temporais em cena (Betti, 2009, p. 37-8).

Vianinha comenta que, em Rasga coração, o seu desejo era o de analisar a concepção do "novo" no engajamento político, especialmente num momento em que o Brasil enfrentava uma ditadura militar. A peça indica que, entre os representantes deste conceito de "novo", estão Luca e seu modo de viver hippie. Para o dramaturgo carioca, a contracultura apresentava inovações importantes na luta política - como a mobilização em favor do meio ambiente iniciada pelo filho de Manguari; no entanto, ela também demonstrava problemas e retrocessos, como uma valorização excessiva do indivíduo e uma tendência para a alienação política e social (representada, por exemplo, por Luca ao usar drogas e procurar discos voadores).

Na visão do autor, a inclinação para o individualismo e a alienação não era a atitude mais adequada para lidar com os problemas brasileiros daquele momento. Vianinha defendia, na verdade, uma mobilização coletiva, de diferentes setores da sociedade, para lutar contra a ditadura (algo simbolizado mais por Manguari e sua militância paulatina, embora o dramaturgo também demonstre que este tipo de engajamento político apresentava contradições, como o fato de o pai de Luca ser militante comunista e funcionário público, almejando até utilizar "pistolões" para conseguir um consultório particular para o filho trabalhar como médico). Vianinha procurava, assim, mostrar a complexidade da luta política no Brasil dos anos 1970, comparando-a, inclusive, com outros momentos da história brasileira (como a era Vargas, em que Manguari era adolescente). Podemos ver aspectos destas ideias em seu prefácio a Rasga coração:

Em segundo lugar, quis fazer uma peça que estudasse as diferenças que existem entre o "novo" e o "revolucionário". O "revolucionário" nem sempre é novo absolutamente e o novo 
nem sempre é revolucionário. [...] Para investigar estas razões, a peça ilumina quarenta anos de nossa vida política, mostrando a repetição do conflito de percepção do verdadeiramente novo. [...] No final, no frigir dos ovos, o revolucionário para mim, o novo, é o velho Manguari. Revolucionário seria a luta contra o cotidiano, feita de cotidiano (Vianna Filho, 1979, p. 13-4).

Assim, Vianinha demonstrava uma visão crítica da contracultura, sendo contrário à busca pela realização individual presente em muitos de seus segmentos:

Ele [Vianinha] não se conformava com as práticas desses grupos [a contracultura e as vanguardas], que vivenciavam um conjunto de valores e de comportamentos voltados acentuadamente à procura da libertação pessoal, quando a seu ver a prioridade de todo artista consciente deveria ser a luta contra a ditadura (Moraes, 1991, p. 209).

Ainda assim, o dramaturgo não deixou de ressaltar certos aspectos positivos de sua luta:

Vianninha ultrapassa o pensamento da sua época, que via no movimento hippie um escapismo, e coloca na boca do jovem [Luca] as palavras que hoje expressariam uma nova forma de luta, a luta pela preservação da natureza, pela ecologia, pelo meio ambiente, possivelmente a única forma de preservar-se a luta do homem, preservando-se o próprio homem da autodestruição (Guimarães, 1984, p. 107).

Não foi possível perceber, até este momento da pesquisa em questão, até que ponto Rasga coração faz um diálogo direto com Hair. Aparentemente, não há referências explícitas ao musical norteamericano nos textos críticos de Vianinha (embora a montagem brasileira de Hair em 1969 nos faça crer que o dramaturgo carioca tivesse conhecimento da peça estadunidense).

De qualquer forma, uma vez que Vianinha analisa, entre outras coisas, a contracultura em Rasga coração, e esta contracultura é o cerne da matéria representada por Hair, há muitos pontos de aproximação entre os jovens do musical americano e os da peça brasileira (Luca e Milena). No entanto, as lutas político-culturais nos contextos americano e brasileiro dos anos 1960 e 1970 apresentam diferenças, e a visão de Vianinha demonstra ser 
muito mais crítica e menos entusiasta deste movimento contracultural do que a dos atores estadunidenses criadores do musical.

\section{Referências}

ANDERSON, David (2002). The Columbia guide to the Vietnam War. New York: Columbia University Press.

BARNES, Clive (1967). The theater: Hair, a love-rock musical, inaugurates Shakespeare Festival's Anspacher Playhouse - contemporary youth depicted in play. The New York Times, 30 out.

BETTI, Maria Sílvia (1997). Oduvaldo Vianna Filho. São Paulo: Ed. USP; FAPESP. (Coleção artistas brasileiros.)

BETTI, Maria Sílvia (2009) Rasga coração, de Oduvaldo Vianna Filho: perspectivas formais da representação sócio-histórica. Revista UniABC Humanas, v. 1, n. 1, p. 21-43.

GROOVY. Cambridge Dictionary. Disponível em: <http://goo.gl/b6LdaP>. Acesso em: 26 jun. 2013.

CAPELLARI, Marcos Alexandre (2007). O discurso da contracultura no Brasil: o underground através de Luiz Carlos Maciel (c. 1970). Tese (Doutorado em História) - Faculdade de Filosofia, Letras e Ciências Humanas, Universidade de São Paulo, São Paulo.

CARDOSO, Irene (2005). A geração dos anos de 1960: o peso de uma herança. Tempo Social, v. 17, n. 2, p. 93-107, nov.

DAMASCENO, Leslie Hawkins (1994). Espaço cultural e convenções teatrais na obra de Oduvaldo Vianna Filho. Campinas: Ed. UNICAMP.

FONTES, Virgínia (1998). Sempre maio: de 1968 a 1998. Disponível em: <http://www.ifcs.ufrj.br/humanas/0012.htm>. Acesso em: 13 out. 2010.

GUIMARÃES, Carmelinda (1984). Um ato de resistência: o teatro de Oduvaldo Vianna Filho. São Paulo: MG Editores Associados.

MARTíNEZ, Horacio Luján (2012). Theodore Roszak (1933-2011): Um contraobituário. Espaço Acadêmico, ano 11, n. 132, p. 151-6, mai.

MORAES, Dênis de (1991). Vianinha, cúmplice da paixão: uma biografia de Oduvaldo Vianna Filho. Rio de Janeiro: Nórdica.

OLIVEIRA, Éwerton Silva de (2012). Análise formal de Death of a Salesman, de Arthur Miller, e Rasga coração, de Oduvaldo Vianna Filho: a utilização do épico. 
Dissertação (Mestrado em Letras) - Faculdade de Filosofia, Letras e Ciências Humanas, Universidade de São Paulo, São Paulo.

PEIXOTO, Fernando (Org.) (1983). Vianinha: teatro, televisão, política - artigos, entrevistas e textos inéditos. São Paulo: Brasiliense.

RAGNI, Gerome; RADO, James (1970). Hair: the American tribal love-rock musical. New York: Pocket Books.

ROSZAK, Theodore (1970). El nacimiento de una contracultura: reflexiones sobre la sociedad tecnocrática y su oposición juvenil. Tradução para o espanhol de Angel Abad. Barcelona: Kairós.

SKIDMORE, Thomas (2003). Uma história do Brasil. Tradução de Raul Fiker. 4. ed. São Paulo: Paz e Terra.

HAIR - 1969 (2008). Teatro musical no brasil, 3 fev. Disponível em: <http:/ /goo.gl/Li16Em>. Acesso em: 25 jun. 2013.

VIANNA FILHO, Oduvaldo (1979). Rasga coração. Rio de Janeiro: SNT.

WOLLMAN, Elizabeth (2006). The theater will rock: a history of the rock musical From Hair to Hedwig. Ann Arbor: University of Michigan.

ZINN, Howard (2010). A people's history of the United States: 1492 to present. New York: HarperCollins.

Recebido em dezembro de 2014.

Aprovado em abril de 2015.

\section{resumo/abstract}

\section{Rasga coração, de Vianinha, e Hair: aproximação e distanciamento num contexto de contracultura}

Éwerton Silva de Oliveira

Considerando a estrutura formal e conteudística das obras, e os movimentos políticos e culturais dos jovens dos anos 1960 e 1970 - dentre eles, a contracultura - no contexto norte-americano e no processo histórico brasileiro (este último incluindo a plena vigência de uma ditadura militar), o presente artigo procura analisar como o musical Hair (1967), dos atores norte-americanos James Rado e Gerome Ragni, e a peça Rasga coração (1974), do dramaturgo brasileiro Oduvaldo Vianna Filho (Vianinha), sobretudo por meio de suas personagens jovens, representam a presença da contracultura (em suas inovações e contradições, 
semelhanças e diferenças) nos Estados Unidos e no Brasil. O diferente enfoque de ambas as peças a este movimento político-cultural também é enfatizado no artigo.

Palavras-chave: teatro brasileiro, teatro norte-americano, contracultura, Oduvaldo Vianna Filho.

\section{Rasga coração, by Vianinha, and Hair: proximity and distance in a counterculture context}

Éwerton Silva de Oliveira

Considering the plays' formal and content structure, and the political and cultural movements of the 60's and 70's youth-the counterculture among them - in the North-American context and in the Brazilian historical process (including the dictatorship present in Brazil in these decades), this article aims to analyze how the musical called Hair (1967), by the American actors James Rado and Gerome Ragni, and Rasga coração (1974), a play by the Brazilian playwright Oduvaldo Vianna Filho (Vianinha), represent the presence of the counterculture, with its innovations and contradictions, similarities and differences, in Brazil and in the United States. This representation is made especially by the young characters of these plays, and the different focus Rasga coração and Hair give to this political-cultural movement is also emphasized in the article.

Keywords: Brazilian theater, North-American theater, counterculture, Oduvaldo Vianna Filho. 